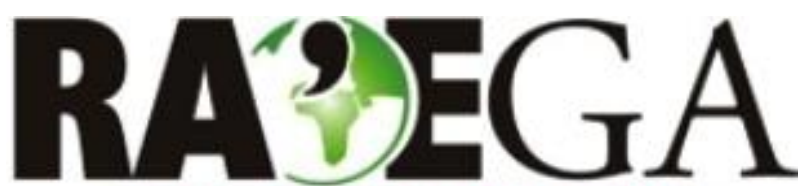

O ESPACCO GEOGRÁFICO EM ANÁLISE

\title{
CIDADES E CONTRA-RACIONALIDADES: OCUPAÇÕES URBANAS EM CAMPINAS/SP (DO PARQUE OZIEL AO JARDIM CAMPO BELO) ${ }^{1}$
}

\section{CITIES AND COUNTER-RATIONALITIES: URBAN OCCUPATIONS IN CAMPINAS/SP (FROM PARQUE OZIEL TO JARDIM CAMPO BELO)}

\section{RESUMO}

\author{
Helena Rizzatti ${ }^{2}$, Adriana Maria Bernardes da Silva ${ }^{3}$
}

A cidade de Campinas/SP, conhecida por sua pujança econômica, é composta também por uma extensa, diversa, fragmentada e empobrecida periferia urbana. Nesse artigo apresentamos parte de nossas pesquisas sobre o processo de urbanização de Campinas, enfatizando a periferização mais recente com início nos anos 1990 e marcada pelas ocupações de terras urbanas. Destacamos as duas maiores ocupações da cidade: a do Jardim Campo Belo e a do Parque Oziel, que somam hoje uma população de aproximadamente 80 mil pessoas. Ao longo das últimas décadas, os moradores dessas duas ocupações traçaram inúmeras ações para produzir e organizar uma fração da cidade de Campinas: construíram as habitações, edificaram igrejas e centros comunitários, distribuíram informalmente redes de energia e água. Seguiram lutando para ter acesso aos serviços públicos (transporte, saúde, educação) e, ao mesmo tempo, resistiram às constantes ameaças de desocupação. Buscamos aqui analisar e problematizar essas ações que permitiram a sobrevivência e a luta dessa população migrante, marginal e/ou excluída, considerando a) a formação do lugar; b) as ações das Associações de Moradores do Bairro; e c) a produção de informações ascendentes colocadas em circulação através de jornais locais e rádios comunitárias. Reconhecemos que nos limites da racionalidade dos sistemas econômico e político hegemônicos gestam-se contra-racionalidades, racionalidades paralelas, voltadas à sobrevivência, à reprodução e à resistência.

PALAVRAS-CHAVE: urbanização, ocupações urbanas, contra-racionalidades, Campinas/SP, Parque Oziel, Jardim Campo Belo

\section{ABSTRACT}

The city of Campinas/SP, known for its economic strength, is also composed of an extensive, diverse, fragmented and impoverished urban periphery. In this paper we present part of our research on the urbanization process of Campinas, emphasizing the most recent peripheralization that started in the 1990s and was marked by the occupations of urban land. We highlight the two largest occupations: the Jardim Campo Belo and Parque Oziel, that totalize a population of approximately 80,000 people organized by themselves to build a portion of the city: they built habitations, churches and community centers, informally distributed water and energy networks. They kept fighting to have access to the public services (transport, health, education) and, at the same time, resisted to the constant threats of vacation. We analyze the actions that allowed the survival and struggle of the migrant, marginal and excluded population, considering a) the place formation; b) the Neighborhood Residents Association's actions; and c) the production of ascending information through newspapers and radios made in these urban occupations.

KEY-WORDS: urbanization, urban occupations, counter-rationalities, Campinas/SP, Parque Oziel, Jardim Campo Belo.

Recebido em: 14/04/2016

Aceito em: 14/06/2017

\footnotetext{
${ }^{1}$ Este artigo é resultado de pesquisa de mestrado parcialmente financiado pela CAPES.

${ }^{2}$ Universidade Estadual de Campinaso,Campinas/SP, e-mail: helenarizzattifonseca@gmail.com

${ }^{3}$ Universidade Estadual de Campinaso,Campinas/SP, e-mail: abernar@ige.unicamp.br
} 


\section{INTRODUÇÃO}

Há sim, insurgência contra o modo de vida proposto pela gestão neoliberal da cidade e recusa da exclusão associada à produção da cidade para o mercado. Nesta insurgência, que tanto pode ser explosiva quanto surda $e$ cotidiana, conjugam-se identidades apenas esboçadas e valores tradicionais; ação organizada e ação espontânea; conquista de territórios e movimentos culturais; táticas de sobrevivência e indignação pela morte de crianças e jovens; ação isolada e fenômenos de multidão; sensibilidade e razão. Como disse Milton Santos (2000), uma outra sensibilidade encontra-se a gestação do presente, envolvendo o aprendizado das ruas, a vitalidade dos espaços opacos... novas linguagens e formas de comunicação. (RIBEIRO, A. C. T., 2013, p. 220)

Campinas/SP participa ativamente da nova divisão territorial do trabalho acolhendo objetos (formas geográficas) e ações (com destaque para as normas) condizentes com a nova vaga de modernizações impulsionada pela globalização. A cidade é hoje lugar para diversas redes privadas e públicas que perpassam o território brasileiro e um centro de informações científicas e econômicas (SANTOS, 2000). Ao analisarmos a história de suas sucessivas transformações, nota-se a constituição de uma importante densidade técnica, científica e informacional ao longo do século XX (SOUZA, 2008).

A cidade apresenta importante função econômica na rede urbana brasileira em virtude de um parque industrial de grandes proporções que vem sendo instalado na cidade a partir do século XX. O processo da "desconcentração concentrada" da metrópole de São Paulo (LENCIONE, 1994), a partir da década de 1970, alavancou sua pujança econômica. É nesse contexto que a cidade se atualiza na divisão territorial do trabalho como um dos mais importantes polos de alta tecnologia do país, centro de produção e distribuição de tecnologia (SANTOS, 2000) e informações.
Todavia, ao mesmo tempo que se moderniza, Campinas também conhece acentuada expansão da pobreza e é, hoje, a terceira cidade com maior número absoluto de população residente em favelas e ocupações do Estado de São Paulo e a décima quinta do Brasil (IBGE, 2011). A cidade acompanha, assim, o processo brasileiro de urbanização, transformando-se nas últimas décadas em uma cidade corporativa e fragmentada (SOUZA, 2008), resultado de uma urbanização corporativa (SANTOS, [1993] 2008) que a caracteriza.

Difusa e espraiada, a cidade sofre um rápido e descuidado aumento de seu perímetro urbano no intuito de i) viabilizar os interesses de especuladores imobiliários, haja vista a sobrevalorização de frações do espaço com a instalação de condomínios fechados, shopping centers, equipamentos comerciais, entre outros; ii) facilitar a implantação de grandes empresas, deixando para segundo plano o atendimento às necessidades da população e, principalmente, dos pobres urbanos.

Configura-se em Campinas, portanto, um espaço urbano que abriga as modernizações, mas que é incapaz de atender às necessidades de parte de sua população. Desse modo, reproduz uma pobreza estrutural e evidencia acentuado esgarçamento da sociabilidade e do tecido urbano. Essa desigualdade socioespacial concretiza-se na existência de espaços luminosos e espaços opacos nos quais não só a ausência de infraestrutura urbana e os problemas sociais demonstram tal desigualdade como também as situações desiguais de acesso à informação entre as diferentes parcelas da cidade.

Ao analisarmos o território campineiro, e com base em Cano \& Brandão (2002), verificamos que há em Campinas uma Macrorregião Norte rica e luminosa e uma Macrorregião Sul pobre e opaca. Tal fragmentação da cidade reflete, inclusive, na distribuição dos teatros, shoppings e museus, majoritariamente instalados na parcela rica, em contraposição a localização dos cortumes, cemitérios, entre outros, na área pobre (HELENE; ANDREOTTI; MARINO, 2011). Essa pobreza, como ocorre em diversas 


\section{CIDADES E CONTRA-RACIONALIDADES: OCUPAÇÕES URBANAS EM CAMPINAS/SP (DO PARQUE OZIEL \\ AO JARDIM CAMPO BELO)}

metrópoles e grandes cidades do país, reflete-se nas lutas e conflitos pelo uso do território condensados, atualmente, nos desígnios das ocupações urbanas

É na parcela Sul da cidade que se localizam as duas maiores ocupações de terras urbanas de Campinas analisadas nesse artigo: o Parque Oziel e o Jardim Campo Belo. Essas frações do espaço urbano foram ocupadas, simultaneamente, nos meses de fevereiro e março de 1997. Hoje, a região do Parque Oziel possui uma população de aproximadamente 30 mil pessoas distribuídas em quatro bairros; e na região do Jardim Campo Belo residem cerca de 50 mil pessoas distribuídas em vinte bairros. $\mathrm{Na}$ figura abaixo estão localizadas essas macroocupações e o centro da cidade no perímetro urbano de Campinas (delimitado em azul).

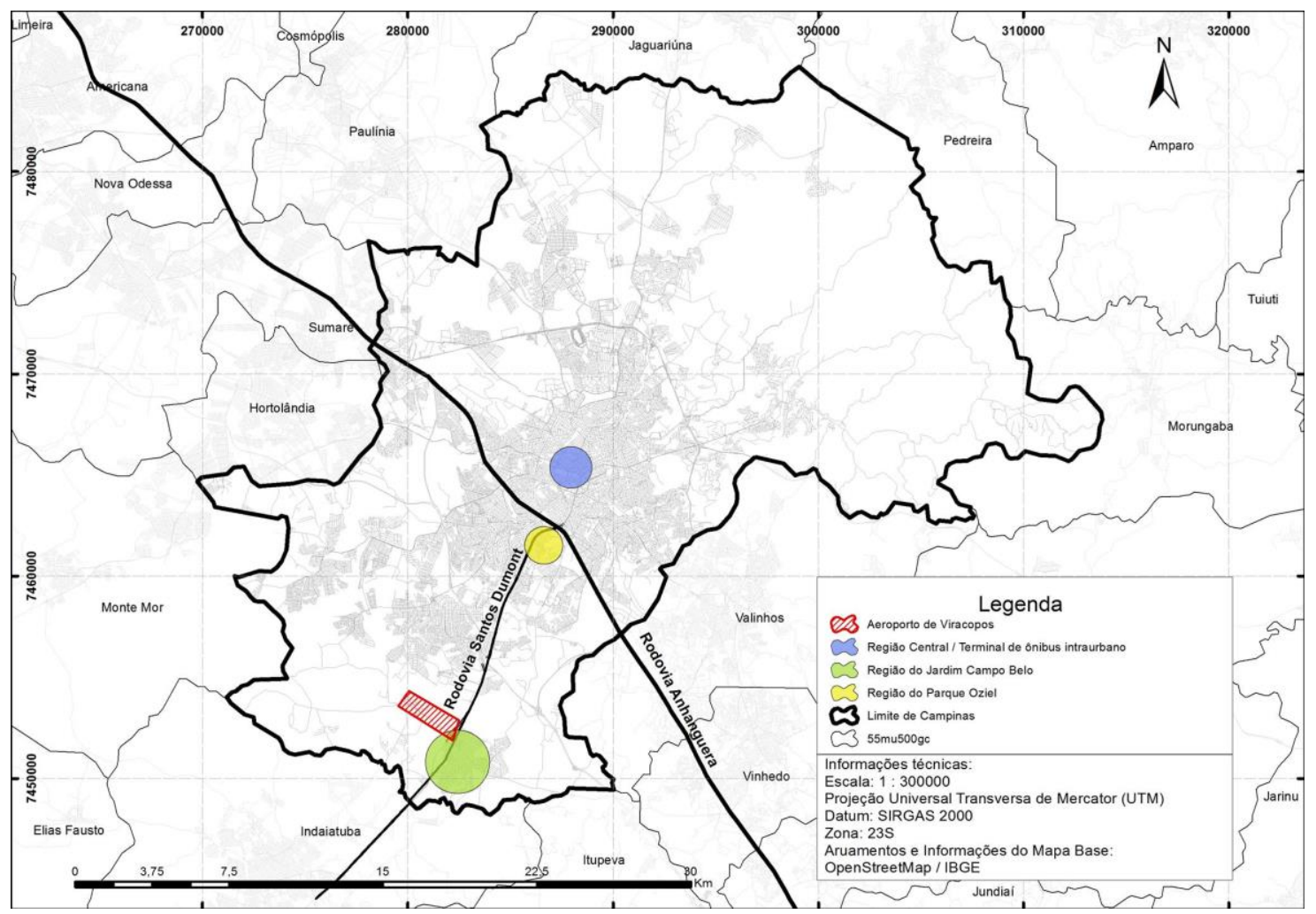

Figura 01 - O perímetro urbano de Campinas/SP e a localização da região do Parque Oziel e da região do Jardim Campo Belo, ao sul da Rodovia Anhanguera (SP-330) Elaboração: CURIOSO, Raphael (2016).

Para compreendermos o processo de urbanização contemporâneo no qual se constituem essas grandes cidades e metrópoles corporativas, faz-se necessário entendermos as contra-racionalidades e insurgências, antigas e novas, tecidas nos entremeios do cotidiano das desigualdades socioespaciais das cidades brasileiras, em seus espaços opacos. Aí se trava a luta pela reprodução, pela sobrevivência e pela criação de novos sentidos à ação emancipatória.

Apresentamos neste artigo de que maneira, na urbanização de Campinas a partir da década de 1990, as ocupações de terras urbanas tornaram-se elementos significativos do espaço urbano. Expomos como as duas ocupações estudadas foram construídas por meio de lutas e conflitos cotidianos; abordamos, ainda, as ações das Associações de Moradores do Bairro, bem como a produção de informações ascendentes através de jornais e rádios produzidos e distribuídos nesses lugares. 


\section{OCUPAÇÕES URBANAS E CONTRA- RACIONALIDADES: BREVE APROXIMAÇÃO}

As ocupações de terras urbanas, cada vez mais presentes nas metrópoles e grandes cidades do Brasil a partir do início dos anos 1980 (RODRIGUES, 1988), são manifestações da urbanização corporativa em andamento no país. Entendemos as ocupações urbanas como a rápida ação de construção de moradias, em terrenos privados e públicos dentro do perímetro urbano, pela população de baixa renda graças a um possível planejamento prévio para escolha do local, do momento e da forma como ocorrerá a ocupação, assim como para construí-la e mantê$\mathrm{la}^{4}$, possibilitando um novo uso do espaço urbano (RIZZATTI, 2014).

Esta forma de habitação na cidade diferencia-se das favelas, pois estas costumam ocorrer de modo individual e mais lento, com a chegada esparsa de famílias de baixa renda que constroem seus barracos para viver. Tal diferença é calcada, portanto, no cuidado com o planejamento das ações de ocupação e na sua realização coletiva e não individualizada nos núcleos familiares.

Entendemos, ainda, as ocupações urbanas como formas-conteúdo reveladoras da crise profunda em que vive a sociedade brasileira, devido a uma histórica e desigual estrutura socioespacial que tem como um de seus pilares a valorização sem controle do espaço urbano voltada a atender aos interesses do capital e corroborada pelo Estado (CORRÊA, 2000; ROLNIK, 2015). Como esclarece Souza (2011, p. 157-158)

Esses 'territórios dissidentes', as 'ocupações', são, muitas vezes, ao mesmo tempo, espaços de experimentação sociopolítica (novas relações de poder, menos ou mais horizontais e anti-heterônomas), político-cultural (cultura desalienante, arte engajada, novas formas de

\footnotetext{
${ }^{4}$ Segundo Rodrigues (1988, p. 14) "as ocupações de terra que ganharam maior expressão nesta década [de 1980] permitem ver com clareza, num curto espaço de tempo [...], o processo de organização e a produção da cidade e da cidadania, na medida em que é um processo que se expressa conflitantemente".
}

socialização) e econômica (circuitos da economia popular-solidária).

A partir dessa compreensão, consideramos que as ocupações urbanas conformam ações com grande potencial de contra-racionalidades (SANTOS, 1996). Estas, sendo deliberadas ou não, são necessárias para a sobrevivência dos pobres na cidade devido ao novo uso dado ao solo urbano ao ser ocupado, bem como às condições de escassez generalizada, à rarefação dos sistemas de engenharia (de circulação, comunicação e energia) e dos fixos públicos (de saúde, educação e lazer), em diversas frações do meio ambiente construído das grandes cidades e metrópoles brasileiras. Nas palavras de Santos (Idem, p. 246)

\begin{abstract}
Essas contra-racionalidades se localizam, de um ponto de vista social, entre os pobres, os migrantes, os excluídos, as minorias; de um ponto de vista econômico, entre as atividades marginais, tradicional ou recentemente marginalizadas; e, de um ponto de vista geográfico, nas áreas menos modernas e mais 'opacas', tornadas irracionais para usos hegemônicos. [...]. O que muitos consideram, adjetivamente, como 'irracionalidade' e, dialeticamente, como 'contra-racionalidade', constitui, na verdade, e substancialmente, outras formas de racionalidade, racionalidades paralelas, divergentes e convergentes ao mesmo tempo.
\end{abstract}

No lugar e no cotidiano constituem-se contra-racionalidades, ou racionalidades paralelas, nos limites da racionalidade do sistema econômico e político hegemônicos. Daí que para Ribeiro (2005) a análise do cotidiano e do lugar impõe a necessidade de refletir sobre o não-dito, o invisível, o anônimo e também sobre aquilo que se duvida valer a pena dizer. Aí onde se dá a continuidade da vida urbana devem posicionar-se aqueles que, "preocupados com o presente, procuram caminhos para um futuro radicalmente democrático" (RIBEIRO, 2005, p.415). 


\section{A URBANIZAÇÃO DE CAMPINAS/SP A PARTIR DE 1990: A PERIFERIA URBANA POBRE MAIS RECENTE}

Segundo Cano \& Brandão (2002) e Mestre (2009), Campinas passou por três períodos de periferização da população de baixa renda, comandados, em grande parte, pelo contínuo processo de industrialização e modernização da cidade, ou seja, pela adaptação às exigências dos novos paradigmas econômicos e, portanto, ao uso corporativo do território (SANTOS \& SILVEIRA, 2001). Conformam-se distintos momentos espaço-temporais em que o território campineiro reestrutura-se constituindo diversas, espalhadas e fragmentadas periferias (RIZZATTI, 2014). Nas palavras de Santos (2008 [1993], p.122), o "processo de urbanização corporativa impõe-se à vida urbana como um todo, mas como processo contraditório, opondo parcelas da cidade, frações da população, formas concretas de produção, modos de vida, comportamentos".

O primeiro período de periferização, com início na década de 1940 até o final de 1960, é marcado pela constituição das primeiras favelas no município em distintos pontos da malha urbana com destaque para a região central e a Macrorregião Norte (que constitui hoje a zona luminosa da cidade). O segundo período de periferização estende-se de 1970 ao final da década de 1980, quando os loteamentos clandestinos $^{5}$ (ou irregulares) são instalados principalmente na área dos Distritos Industriais de Campinas (DICs), na Macrorregião Sul da cidade.

O terceiro e atual período de periferização tem início na década de 1990, quando as ocupações de terras urbanas são a principal forma utilizada pelos trabalhadores espoliados para conseguir uma moradia. Essa periferia mais recente tem grande contingente populacional e situa-se no extremo sul da Macrorregião Sul de

\footnotetext{
5 Para Santos (1990, p. 43) "Uma resposta à problemática da habitação popular foi [...] a disseminação dos chamados loteamentos 'clandestinos', ou irregulares, isto é, formas de urbanizar desobedientes, em parte ou no todo, aos regulamentos vigentes [...]"
}

Campinas, denominada Grande Região (GR) Sul (esta GR apresentou um crescimento populacional ao redor de $10 \%$ ao ano, entre 1991 e 2000 , e $3,1 \%$ ao ano, entre 2000 e $2010{ }^{6}$ ).

Cabe destacar que, diferentemente dos momentos anteriores, a periferização mais recente é caracterizada, de um lado, pela expansão dos loteamentos murados e condomínios de média e alta renda instalados majoritariamente na Macrorregião Norte; e, por outro lado, pela ampliação da pobreza urbana que se instala através de ocupações organizadas e em terrenos relativamente bons (LOPES, 1988; PMH, 2011) na Macrorregião Sul.

O total das ocupações urbanas em Campinas distribuiu-se do seguinte modo ao longo do tempo: $4 \%$ na década de 1960; $29 \%$ em 1970; $21 \%$ nos anos de 1980; $44 \%$ na década de 1990 e $2 \%$ entre os anos de 2000 e 2005 (Plano Diretor de Campinas - PMC, 2006). Nota-se a concentração de tais ações em 1990, com destaque para as macro-ocupações urbanas nas regiões do Parque Oziel e do Jardim Campo Belo devido aos tamanhos e níveis ${ }^{7}$ de organização.

De 2005 até hoje não foram contabilizadas novas ocupações que tenham se mantido na cidade, embora várias tenham se instalado nesse período de modo efêmero. De acordo com os dados disponibilizados pela Prefeitura Municipal de Campinas e pelo IBGE, constatou-se apenas o adensamento da população nas ocupações anteriores. Porém, por meio da realização de trabalhos de campo, é notável o surgimento de novas pequenas ocupações nas margens das linhas férreas desativadas que são, em sua

\footnotetext{
${ }^{6}$ Entre as Grandes Regiões (Norte, Leste, Sudoeste, Sul e Noroeste), os maiores índices de crescimento populacional no período foram: entre 1991 e 2000, a GR Noroeste teve índice de $15,1 \%$ ao ano; e entre 2000 e 2010, a GR Sudoeste com $1,4 \%$ ao ano, metade da taxa na GR Sul neste mesmo período. As GRs Norte e Leste compõem a Macrorregião Norte e as GRs Sul, Sudoeste e Noroeste compõem a Macrorregião Sul.

${ }^{7}$ Além delas, existem ainda mais duas ocupações de grande porte na cidade, ambas na região dos DICs: a ocupação Nossa Senhora Aparecida, constituída em 1994, e a Eldorado Carajás, que data de 1996 (GARCIA, 2010).
} 


\section{CIDADES E CONTRA-RACIONALIDADES: OCUPAÇÕES URBANAS EM CAMPINAS/SP (DO PARQUE OZIEL AO JARDIM CAMPO BELO)}

maioria, áreas públicas federais dentro do perímetro municipal (RIZZATTI, 2014).

Santos (2002), analisando a urbanização de Campinas nas duas últimas décadas do século XX, ajuda-nos a compreender a escalada das ocupações urbanas ao ponderar que

Pouco ou quase nenhum investimento público fora destinado à estruturação básica do espaço da cidade e dos serviços urbanos, fazendo com que esta tenha acumulado, ao longo das duas últimas décadas [1980 e 1990], um catastrófico déficit de oferta de condições gerais. Como costuma dizer Cândido Malta, a sociedade convive com 'um governo cada vez mais pobre, enfrentando cidades cada vez mais caras'. [...] O cenário urbano resultado do padrão de acumulação capitalista destas três últimas décadas [1970, 1980 e 1990] apresenta multidões de migrantes despejados nas favelas, cortiços e na periferia distante, oferta reduzida de emprego no mercado formal, subemprego marginal e desemprego. A fotografia se completa com uma periferia descontroladamente horizontalizada e, no centro da cidade, uma verticalização de controle perdido, intercalados de vazios urbanos, ociosamente estocados, aguardando infra-estrutura que cada vez mais se completa, reforma-se e se transforma [...] (p. 318).

Segundo dados do IBGE (2010) e da PMC (Plano Diretor - PMC, 2006), nos primeiros dez anos do século XXI, houve diminuição considerável da população residente em domicílios nos aglomerados subnormais ${ }^{8} \mathrm{em}$ relação à década de 1990 , passando de $8,8 \%$ ao ano, entre 1990 e 2000, para 1,5\% entre 2000 e 2010. Assim, entre 1991 e 2000, o acréscimo populacional da população de baixa renda foi de 61.198 pessoas; de 2000 a 2010, esse acréscimo foi de 20.385 pessoas (o equivalente a um terço da década anterior). Porém, em ambas as

\footnotetext{
${ }^{8}$ Segundo o IBGE (2011, s/n) os aglomerados subnormais são um conjunto de, no mínimo, 51 unidades habitacionais carentes de serviços públicos essenciais, ocupando, ou tendo ocupado até período recente, terreno de propriedade alheia (pública ou particular) e dispostas, em geral, de forma desordenada e densa.
}

décadas, a taxa de crescimento ao ano da população total, de 1,5\% entre 1990 e 2000 e $1,1 \%$ na década seguinte, foi inferior à da população carente de moradia ${ }^{9}$, que foi de $8,8 \%$ na primeira década analisada e 1,5\% entre 2000 e 2010. Ou seja, a população pobre cresceu em ritmo mais acelerado do que a população total da cidade entre 1990 e 2010. É possível observar esse ritmo de crescimento descompassado entre a população total e a população residente em aglomerados subnormais e as porcentagens destes no município na tabela 1 , com base nos dados do Plano Municipal de Habitação de Campinas (PMH, 2011).

\footnotetext{
9 Consideramos a população carente de moradia tanto as famílias que não possuem uma moradia como as famílias que residem em casas em péssimas condições devido à quantidade de pessoas residindo ou à estrutura da residência.
} 


\section{CIDADES E CONTRA-RACIONALIDADES: OCUPAÇÕES URBANAS EM CAMPINAS/SP (DO PARQUE OZIEL AO JARDIM CAMPO BELO)}

Tabela 01 - População total, quantidade de pessoas residentes em domicílios subnormais e porcentagem de domicílios subnormais em Campinas/SP (1991, 2000, 2010).

\begin{tabular}{|c|c|c|c|}
\hline & 1991 & $\mathbf{2 0 0 0}$ & $\mathbf{2 0 1 0}$ \\
\hline População total (em pessoas) & 847.287 & 969.386 & 1.080 .113 \\
\hline População residente em domicílios subnormais (em & $\begin{array}{c}63.449 \\
(7,49 \%)\end{array}$ & $\begin{array}{c}127.647 \\
(13,2 \%)\end{array}$ & $\begin{array}{c}148.032 \\
(13,8 \%)\end{array}$ \\
\hline pessoas) & 5,7 & 13,17 & 13,4 \\
\hline
\end{tabular}

Fonte: PMH (2011)Tabulação: autoria própria (2013)

De acordo com o $\mathrm{PMH}$, o déficit habitacional de Campinas, em 2010, era de mais de 65 mil domicílios, equivalentes a 13,38\% do total de habitações da cidade. Dentre estes, 30.800 são realmente de déficit, ou seja, há ausência quantitativa de domicílios, e 35.500 caracterizam inadequação habitacional em assentamentos precários. O Plano ressalta ainda que são mais de 22 mil domicílios com renda entre 0 e 3 salários mínimos e mais de 11.300 com renda entre 3 e 5 salários mínimos. Campinas apresenta, assim, mais de $13 \%$ da sua população residente em situação precária, ocupando, segundo o IBGE (2011), a quarta posição do Estado de São Paulo nesse quesito, atrás apenas das cidades de São Paulo, Guarulhos e São Bernardo do Campo. Com relação ao número de domicílios em aglomerados subnormais, a cidade ocupa a mesma posição na mesma sequência de cidades do Estado de São Paulo.

Relembramos que, entre 1986 e 2008, não houve plano nacional de habitação em larga escala. Além disso, nesse período, as condições gerais de produção impostas pelo sistema capitalista foram calcadas nas diretrizes do modelo neoliberal elencadas no Consenso de Washington (CANO, 2011) que atingiram duramente as cidades brasileiras (SILVEIRA, 2007). Diante da privatização das infraestruturas e serviços públicos, do arrocho dos salários, da precarização do trabalho e da mínima intervenção do Estado, a população brasileira de baixa renda ficou sem opções formais de moradia. Soma-se a isso as diretrizes do Banco Mundial para inserção do modelo de habitação baseado em propriedades privadas unifamiliares em contraposição a diversas opções ainda existentes no mundo, como as terras comunais características, por exemplo, de diversas sociedades asiáticas (ROLNIK, 2015).

Nesse contexto, eclodem conflitos urbanos e ganham força ações de ativismos e movimentos sociais que vinham sendo criados desde o final da Ditadura Militar, quando se formaram importantes movimentos sociais, como o Movimento dos Trabalhadores Sem Terra (MST), de destaque internacional, e a Assembleia do Povo de Campinas (AsP), de destaque nacional, ambos atuantes já no início da década de 1980. A capacidade de organização dessa população aumentou devido ao acesso à informação e elaboração de estratégias para ocuparem terrenos e imóveis, públicos e privados, sem uso e vazios, rurais e urbanos, cada vez mais bem localizados no tecido urbano. Como afirmou Jacobi (1982, p. 69)

As invasões [ocupações de terra urbana e rural] tocaram fundo nas raízes da sustentação do sistema econômico e político vigente, pois mexeram com a questão da propriedade privada, tornando audível mudanças na legislação do uso da terra e colocaram em pauta dois temas contrapostos: o do direito à habitação e o do direito à propriedade. A visão clássica assegura ao proprietário o direito de usufruto da propriedade e sob essa ótica as ocupações representam violação grave. Entretanto, as inaceitáveis condições de vida dos pobres das cidades, que um sistema socialmente desigual não fez senão acentuar, modificam o enfoque da questão. 


\section{CIDADES E CONTRA-RACIONALIDADES: OCUPAÇÕES URBANAS EM CAMPINAS/SP (DO PARQUE OZIEL AO JARDIM CAMPO BELO)}

Para a produção dessa nova formaconteúdo da periferia urbana - que são as ocupações de terras - são necessárias diversas estratégias e contra-racionalidades abrangentes para a organização dessas áreas: da viabilização de infraestruturas urbanas e lutas pela sua formalização até o acesso à informação sobre o mundo, o país, a cidade e o lugar onde moram. $E$ são esses aspectos que buscamos apresentar no próximo item, enfatizando a análise das macroocupações do Jardim Campo Belo e do Parque Oziel.

\section{CONTRA-RACIONALIDADES NAS OCUPAÇÕES URBANAS DO PARQUE OZIEL E DO JARDIM CAMPO BELO}

Ocupar estrategicamente o espaço urbano tem sido, diante da falta de moradia, uma busca por formas alternativas de racionalidade face ao modelo dominante de produzir a cidade. Da mesma forma, manter-se na ocupação (face às forças repressivas e legais de preservação da propriedade privada em detrimento das necessidades sociais), estruturar e organizar cotidianamente o novo lugar de moradia implica em outras tantas formas alternativas de racionalidade: de edificações, abertura de vias de circulação, distribuição de energia e água, abastecimento, comércio, trabalho, lazer, segurança, comunicação, sociabilidade, entre tantas outras.

Conforme assinalou Ribeiro (2013), emerge nas metrópoles dos países periféricos uma nova sistematicidade, latente, que aponta para uma "outra cidade" potencial, indiciada pelo teor dos conflitos urbanos e de difícil apreensão por discursos únicos. Na gestação desta "outra cidade" há resistência aos projetos dominantes para as grandes cidades,

porém os conteúdos desta resistência não se limitam à contestação direta desses projetos, incluem, de forma muito mais larga, a experiência, a criatividade, as conquistas, as vozes e os sonhos de muitos outros (Idem, p. 220).
Para nos aproximarmos dessa "outracidade" e suas contra-racionalidades e insurgências prementes para a sobrevivência dos sujeitos, exporemos resumidamente i) como as ocupações foram constituindo-se ao longo do tempo, isto é, a formação do lugar; ii) como se organizam as Associações de Moradores do Bairro; e iii) como produzem e acessam informações sobre o lugar que constroem e sobre a cidade de modo geral. Ainda conforme Ribeiro (2013, p. 221), com o reconhecimento da sistematicidade latente da "outra cidade" potencial, "modifica-se a leitura da ação social e os futuros pensáveis".

As ocupações urbanas estudadas instalaram-se em 1997 e mantêm-se estruturadas até hoje em território campineiro. Ambas ocorreram através de prévia organização das lideranças dos movimentos sociais atuantes na cidade de Campinas que tinham conhecimento da ociosidade de grandes loteamentos de terrenos privados. Os líderes tiveram auxílio do Movimento do Trabalhadores Rurais Sem Terra (MST), principalmente, para o momento da ocupação, quando é preciso um alto contingente de pessoas para realizar atividades de muito consumo de energia, como capinar e montar barracos com rapidez. Para a manutenção da estrutura inicial da ocupação, as próprias lideranças organizaram-se e contaram com a ajuda da população ocupante e algumas parcelas da sociedade de Campinas, como, por exemplo, aquelas envolvidas com as redes de distribuição de alimentos, remédios, roupas, entre outras doações.

Como nos lembra Santos (1990), nos lugares onde os habitantes das favelas e ocupações puderam organizar-se politicamente, o processo de expulsão não ocorreu ou, quando ocorreu, foi de forma lenta, fato que também se confirma, em grande medida, nas ocupações do Parque Oziel e do Jardim Campo Belo. Ambas sofreram, por dez anos, ameaça da remoção, embora tal ação não tenha ocorrido em nenhuma delas. A ocupação do Parque Oziel está, hoje, em processo de regularização e a do Jardim Campo Belo provavelmente será removida, porém ainda 


\section{CIDADES E CONTRA-RACIONALIDADES: OCUPAÇÕES URBANAS EM CAMPINAS/SP (DO PARQUE OZIEL AO JARDIM CAMPO BELO)}

sofrerá alterações por estar na curva de ruídos do Aeroporto Internacional de Viracopos.

A região do Jardim Campo Belo dista de quinze quilômetros do centro de Campinas (Figura1), tendo sido loteada na década de 1950, em um período em que o perímetro urbano da cidade se expandiu excessivamente (MESTRE \& FONSECA, 2011). Na década de 1970, essa área foi delimitada para a futura expansão do aeroporto Viracopos, porém ficou sem uso até a ocupação em 1997. Quando tal ocupação ocorreu, existiam na área apenas cinco bairros com poucas moradias. Abaixo apresentamos imagens do início dessa ocupação e de como ela está hoje

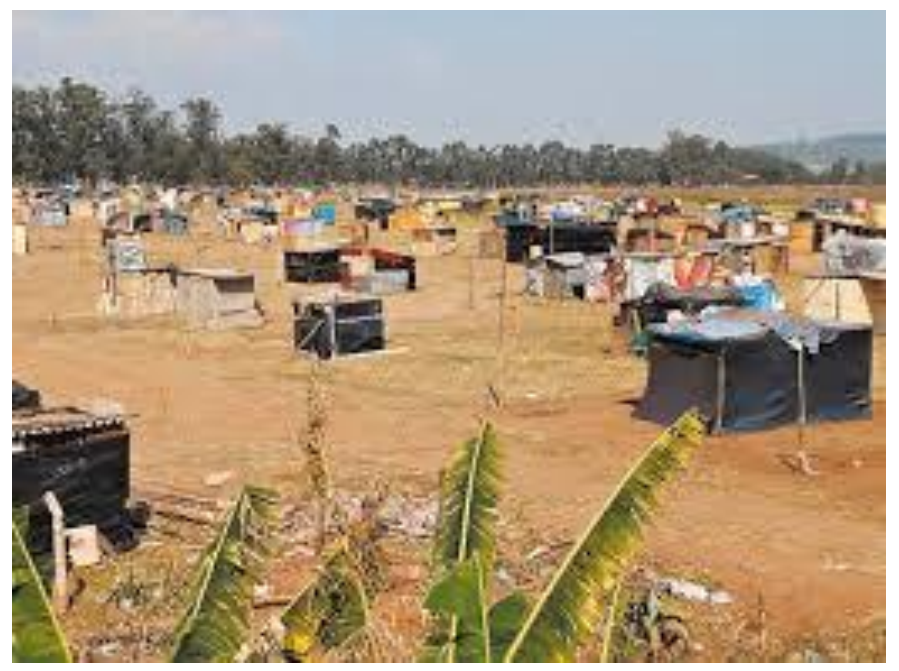

Foto 01 - Início da ocupação da região do Jardim Campo Belo em Campinas/SP (1997) Fonte: www.g1.globo.com ${ }^{10}$

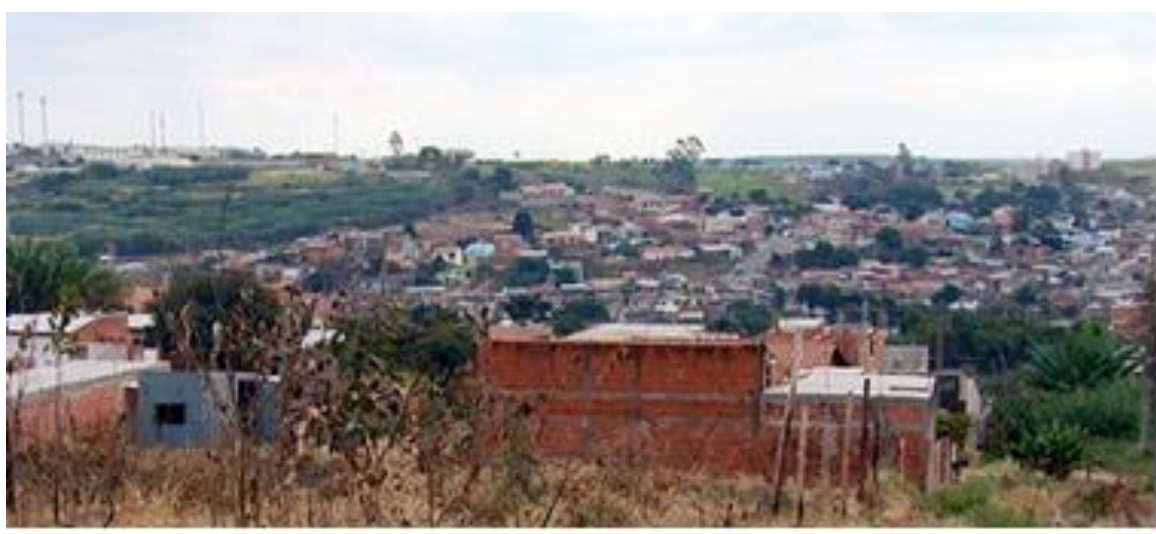

Foto 02- A região do Jardim Campo Belo hoje (2013). Fonte: www.g1.globo.com ${ }^{11}$

\footnotetext{
10 Disponível em: < http://g1.globo.com/sp/campinas-regiao/noticia/2013/05/com-4-dps-regiao-de-campinas-concentra-umquarto-dos-crimes.html>

11 Disponível em: <http://g1.globo.com/sp/campinas-regiao/noticia/2013/05/com-4-dps-regiao-de-campinas-concentra-umquarto-dos-crimes.html>
} 


\section{CIDADES E CONTRA-RACIONALIDADES: OCUPAÇÕES URBANAS EM CAMPINAS/SP (DO PARQUE OZIEL AO JARDIM CAMPO BELO)}

Atualmente vem sendo constituído o vigésimo bairro da região e apenas um deles, o Jardim São Domingos, é completamente regular. Os terrenos ocupados são majoritariamente privados, pertencentes a indústrias, à Igreja Católica e a grandes e pequenos proprietários de terras. Com o início da expansão do aeroporto, no ano de 2008, veio o último momento de grande receio de remoção. Porém, em razão da pressão social, das dificuldades econômicas e do desgaste político que a remoção de 7.500 famílias causaria à gestão municipal, o local para a expansão desse macrofixo foi alterado (agora se direciona a uma área rural da cidade). Ainda assim, tal alteração causou, até o momento, a remoção de 215 famílias e o agravamento de problemas ambientais, pois a expansão ocorre em um terreno acidentado e com diversos mananciais. Entretanto, a alteração desse planejamento corporativo é, até certo ponto, vitória dos moradores da ocupação (RIZZATTI, 2015a). Na Figura 2 é apresentada a região do Jardim Campo Belo com mais detalhes.

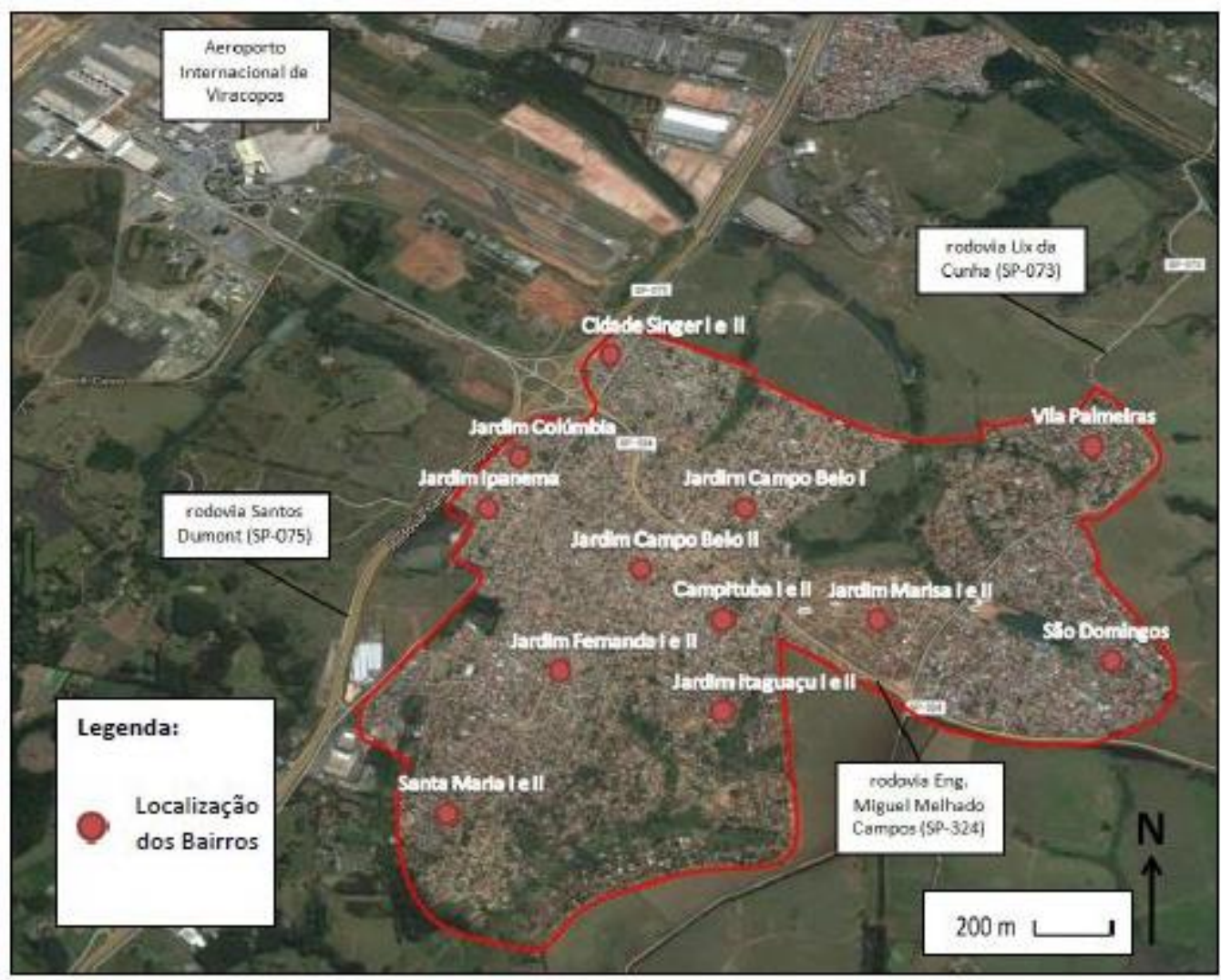

Figura 02 - Principais bairros que compõem a região do Jardim Campo Belo em Campinas/SP.Fonte: MOYSES (2016).

É possível visualizar na imagem os principais bairros que compõem a região do Jardim Campo Belo, porém tal configuração é difícil de delimitar detalhadamente devido à dinâmica conflituosa da região, ou seja, diferentes órgãos e autarquias municipais (como a CPFL, a SANASA e as diversas Secretarias Municipais) compreendem de maneira diversificada a divisão dos bairros. Relembramos que apenas o bairro na extrema direita (São Domingos) é totalmente composto por moradias regulares. Os outros são constituídos por residências em diversas situações de construção e legalidade mesclando-se casas completamente construídas e regularizadas com barracos, com 


\section{CIDADES E CONTRA-RACIONALIDADES: OCUPAÇÕES URBANAS EM CAMPINAS/SP (DO PARQUE OZIEL AO JARDIM CAMPO BELO)}

casas no reboco, casas em construções, entre outras situações.

No ano de 2008, foi implementado o Programa Social VIP-Viracopos ${ }^{12}$, um programa de reurbanização e regularização destinado às regiões do Campo Belo e do Parque Oziel, simultaneamente. Esse projeto social faz parte do Programa de Assentamentos Precários vinculado ao Programa de Aceleração de Crescimento (PAC), de âmbito federal. Foi através do VIPViracopos que infraestruturas e serviços urbanos formais foram instalados em ambas as regiões.

No Jardim Campo Belo foram implantados postos de saúde, escolas, creches e houve aumento das linhas de ônibus que atendem a área; foram pavimentadas as principais ruas por onde o transporte público passa e foi inserida rede de água e esgoto, finalizada desde 2010, mas até hoje desativada. Foi dado início, também, ao processo de regularização da área. Todavia, os bairros com maior contingente populacional localizam-se na curva de ruído do aeroporto o que inviabiliza a regularização. As opções para esse entrave são: apropriar as casas para o ruído; construir um conjunto habitacional na área e transferir as famílias; ou fazer a remoção dessa população para outra parcela da cidade. No momento, a última opção é a menos cogitada pela Prefeitura e a segunda a mais.

Apesar das ações do poder público, essa ocupação é considerada pela própria Prefeitura de Campinas como a mais vulnerável

\footnotetext{
12 O nome dado ao Programa (VIP Viracopos) merecer ser refletido. Duas ponderações iniciais são necessárias: i) é uma estratégia de marketing corporativo, pois dá a entender que os gestores do Aeroporto Internacional de Viracopos têm preocupação com as mazelas sociais existentes em seu entorno e ii) retira a identidade dos bairros ao não dar visibilidade à sua toponímia. Ora, para a eficácia dos ajustes espaciais prevalece um trabalho constante de produção da invisibilidade orquestrado por agentes hegemônicos que não deixa vir ao debate as condições críticas de difusão do meio técnico-científico-informacional (Santos, 1996), da acumulação por espoliação (Harvey, 2004) e o consequente aprofundamento da pobreza nas cidades. Dois campos operacionais são mobilizados para garantir o consenso e a invisibilidade: a gestão da pobreza e o controle da informação e da comunicação.
}

socialmente, sendo que a necessidade de infraestrutura e serviços urbanos continua premente. Desde o início deste programa, muitas famílias já foram embora da área devido ao aumento do custo de vida e à valorização dos terrenos; deslocaram-se para assentamentos rurais ou outras ocupações urbanas mais recentes na cidade e na sua região metropolitana. Isso aconteceu nas duas ocupações estudadas onde o projeto de reurbanização foi implantado. Como escreve Santos (1990, p. 50)

Uma das razões pelas quais os pobres tendem a não se fixar, sendo levados para localizações sempre mais periféricas, vem dos custos dos serviços. [...]. Isto significa que a chegada de melhoramentos urbanos a uma área conduz, a médio prazo, à expulsão dos pobres, pela impossibilidade de arcarem com as respectivas despesas.

Além disso, houve remoção de algumas residências no bairro mais próximo do aeroporto, ação arbitrária e conduzida pelo consórcio Aeroportos Brasil, vencedor da concessão do Aeroporto de Viracopos. Tais ações ocorreram sem a autorização do poder público e sob muita truculência. Residências de alvenaria foram derrubadas sem que os moradores recebessem aviso prévio, tampouco ressarcimento. Os atos praticados não foram sequer precedidos do acompanhamento do Conselho de Direitos Humanos, representantes da Prefeitura, Câmara Municipal, Ordem dos Advogados do Brasil, Defensoria Pública, Conselho Tutelar, entre tantos outros. Iniciaram, sem mandato judicial, um cerco às moradias e às pessoas residentes no bairro e, com quatro tratores de grande porte da Construtora Constran, destruíram as casas. Não houve, até o momento, nenhum tipo de respaldo, auxílio, ajuda ou indenização às pessoas afetadas (MANIFESTO, 2013).

A região do Parque Oziel, por sua vez, foi loteada na década de 1980 e dista apenas 5 quilômetros do centro. Trata-se de uma área de média valorização imobiliária, localizada próxima do Terminal Central de Ônibus Urbano, de hotéis 


\section{CIDADES E CONTRA-RACIONALIDADES: OCUPAÇÕES URBANAS EM CAMPINAS/SP (DO PARQUE OZIEL AO JARDIM CAMPO BELO)}

de alto padrão e com acesso às Rodovias Santos Dumont, Anhanguera e Bandeirantes. Devido à localização, o processo de ocupação foi mais conflituoso e tenso do que na região do Jardim Campo Belo, haja vista a morte de quatro líderes em apenas seis meses e a entrada com pedido de despejo feito diversas vezes por parte dos proprietários. A região é composta por quatro bairros e um deles ainda não tinha sido loteado quando da ocupação, o Gleba B, que com o processo de regularização em andamento tornarse-á o bairro Vila Taubaté. Os terrenos pertenciam principalmente a dois proprietários de terras que, hoje, estão sendo indenizados pela prefeitura. Na foto 3 mostramos parte dessa ocupação no ano de 2013

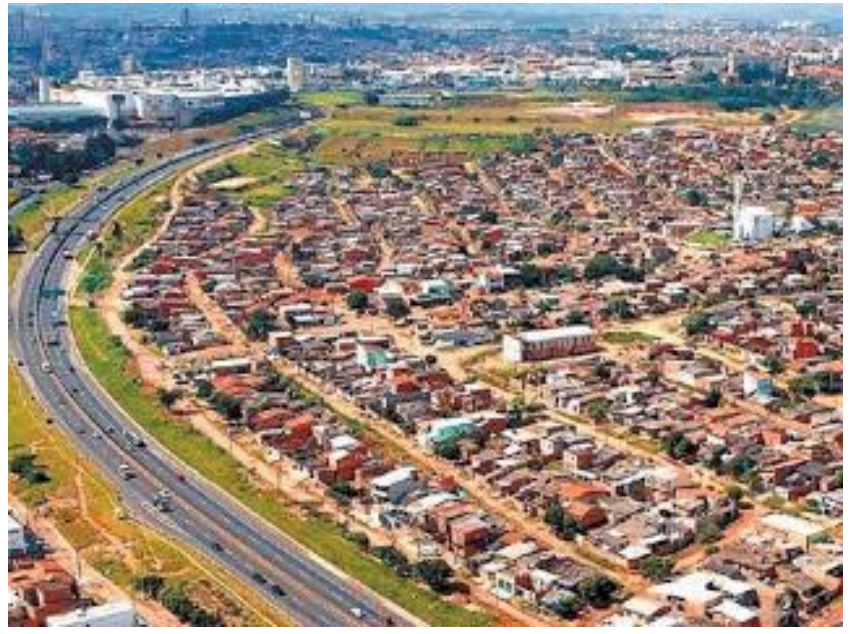

Foto 03 - Ocupação urbana da região do Parque Oziel em Campinas/SP (2013). Fonte: www.administrandooziel.blogspot.com.br ${ }^{13}$ 
RIZZATTI,H. e SILVA, A.M.B.

CIDADES E CONTRA-RACIONALIDADES: OCUPAÇÕES URBANAS EM CAMPINAS/SP (DO PARQUE OZIEL

AO JARDIM CAMPO BELO)

Na Figura 2, abaixo, mostramos com mais Parque Oziel: detalhes os bairros que compõem a região do

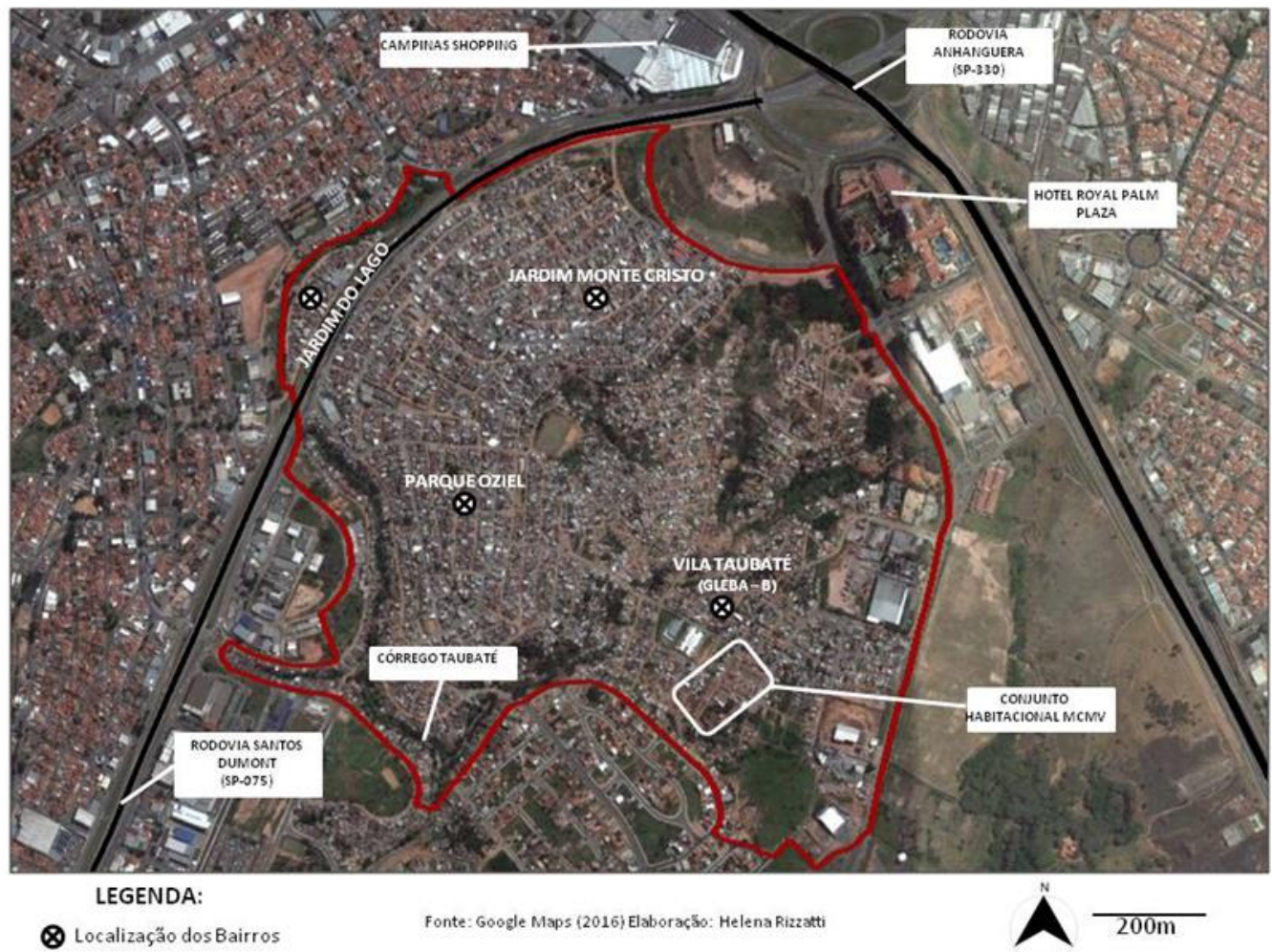

Figura 03 - Bairros que compõem a região do Parque Oziel em Campinas/SP. Fonte: Google Maps (2016) Elaboração: autoria própria (2017).

Na imagem acima é possível visualizar os quatro bairros que compõem a região do Parque Oziel, as Rodovias Anhanguera e Santos Dumont que praticamente margeiam a área, o Shopping Campinas e a o Hotel Royal Palm Plaza. Dentro do bairro Vila Taubaté (antigo Gleba B) está indicada a localização do conjunto habitacional Minha Casa, Minha Vida finalizado no ano de 2014.

No quadro 1, abaixo, apresentamos as principais etapas de negociação dessa área de grande disputa 
Quadro 01 - Decretos da prefeitura para a atual região do Parque Oziel em Campinas/SP

\begin{tabular}{|l|l|}
\hline ANO & \multicolumn{1}{c|}{ DECRETOS } \\
\hline 1970 & Decreto 3625/70 - Aprovação do loteamento Jardim do Lago Continuação \\
\hline 1999 & Decretos 13090 e 13123 - Declaração de Interesse Social para fins de desapropriação \\
\hline 2001 & $\begin{array}{l}\text { Decretos 13583, 13584, 13600 e 13601 - Declaração de Interesse Social para fins de } \\
\text { desapropriação }\end{array}$ \\
\hline 2004 & Decretos 14918 e 14919 - Revalida a Declaração de Interesse Social \\
\hline 2005 & Decretos 15057 e 15109 - Revalida a Declaração de Interesse Social \\
\hline 2005 & $\begin{array}{l}\text { Decreto 12257 - Institui a “Comissão de Análise e Pagamento de Indenização em } \\
\text { procedimentos referentes ao Parque Oziel, Jardim Monte Cristo e Gleba B" }\end{array}$ \\
\hline 2006 & $\begin{array}{l}\text { Contratação da COHAB para desenvolver os trabalhos relacionados à 1a fase do } \\
\text { processo de regularização }\end{array}$ \\
\hline 2006 & Lei Complementar 15 - Plano Diretor - Área gravada como ZEIS de Regularização \\
\hline 2007 & $\begin{array}{l}\text { Decreto 15760 - “Dispõe sobre a permissão de uso, aos atuais ocupantes, das áreas } \\
\text { do loteamento Jardim do Lago Continuação e Gleba B, declarada de interesse social } \\
\text { para fins de regularização dos loteamentos Parque Oziel/Jardim Monte Cristo/Gleba } \\
\text { B” }\end{array}$ \\
\hline
\end{tabular}

Fonte: 3ㅇ Seminário de Habitação Região Metropolitana de Campinas/PMC e Agemcamp (2007) Organização: autoria própria (2013)

Nessa região, o projeto VIP-Viracopos instalou dois postos de saúde, pavimentou as principais vias, implantou e ligou as redes de saneamento básico e deu início ao processo de regularização em andamento até hoje. Iniciada em 2008, parte da regularização é financiada pelo município e parte é paga pelos moradores. 0 valor pago por estes últimos é de $\mathrm{R} \$ \mathbf{0 , 2 5}$, por metro quadrado, dos lotes residenciais; e $R \$ 0,40$, por metro quadrado, dos lotes utilizados para fins comerciais, ambos pelo período de vinte anos (GHILARDI, 2012). Além disso, foi construído um conjunto habitacional na Vila Taubaté que pretende abrigar todas as famílias da Gleba B.

Para conseguir sobreviver no início de ambas as ocupações, os moradores criaram redes informais através de "gatos" na fiação elétrica e de mangueiras doadas pela SANASA-Campinas para trazer água de recursos hídricos próximos da área até perto de seus barracos. No caso do Parque Oziel, a aquisição das mangueiras só ocorreu após a ocupação da SANASA pelos moradores da região em 1998. Estes foram estimulados pelos próprios líderes a construírem casas de alvenaria o mais rapidamente possível com o intuito de dificultar sua remoção por parte da Prefeitura. No Parque Oziel foram construídos, na madrugada em que ocorreu a ocupação, uma igreja e um centro comunitário com o mesmo objetivo. O centro foi utilizado durante o primeiro ano como cozinha e escola comunitárias.

As Associações de Moradores do Bairro foram, e ainda são, de extrema importância para sustentar a vida de relações nessas ocupações. Muitos líderes iniciaram sua atuação já no momento da ocupação e até hoje permanecem nessa função. As principais atividades das Associações estão voltadas à luta pela regularização de terras, serviços de saúde (dentistas, especialidades médicas), eventos lúdicos (como feiras, festas) e facilidade de acesso dos moradores aos Programas de Transferência de Renda (PTR), alimentação (Prato Cheio), lazer (oficinas) e educação (grupos de acompanhamentos, cursinhos populares, centros de cultura) existentes nos bairros sob sua liderança. Além disso, os líderes têm a possibilidade de participar da política municipal através dos Conselhos dos órgãos municipais, das reuniões do Orçamento Participativo, entre diversas outras, todas opções com grandes limitações para uma participação minimamente democrática. Ou seja, a existência desses 


\section{CIDADES E CONTRA-RACIONALIDADES: OCUPAÇÕES URBANAS EM CAMPINAS/SP (DO PARQUE OZIEL AO JARDIM CAMPO BELO)}

mecanismos não significa uma efetiva participação popular na política, como notamos ao participar dessas atividades, mas é uma oportunidade para compreender os mecanismos do Estado e, assim, fortalecer suas lutas.

A importante função política que essas associações possuem vai além da esfera institucionalizada da vida urbana; anseiam por formalizar direitos, dignidade e esperança. Produzem documentos que formalizam parcelas da vida de uma população que vive em área irregular, apartada de direitos sociais. São elas que produzem os comprovantes de residência utilizados para acessar os serviços públicos, conseguir emprego, ter acesso a programas sociais etc. Trata-se da produção de uma informação formal através da organização do cotidiano dessa população, sem esperar pela autorização do poder público. Como bem analisado por Souza (2011, p. 156)

as associações de moradores exercem o papel de agências de 'intermediação jurídica' (no sentido de uma juricidade alternativa, não estatal) [...]. Transação de compra e venda contam, [...] pelo Brasil a fora, com líderes de associações de moradores como testemunhas; as associações de moradores 'oficializam' tais transações e os documentos daí decorrentes muitas vezes um simples papel escrito à mão -, invocando um poder normativo e regulador geralmente reconhecido pelos moradores, por meio do carimbo da entidade e da assinatura de um representante seu. [...]. É assim que a alquimia popular, ditada pela necessidade, determina, sob a mediação de uma instância microlocalmente reconhecida como possuindo legitimidade normativa também nesse terreno.

É importante lembrar que para a produção dos comprovantes de residência, cartazes, panfletos e outros materiais que as Associações produzem e distribuem, é necessário que as lideranças tenham acesso à tecnologia: computadores, impressoras, cartuchos, caixas de som, carros etc. Com esses objetos eles fazem diversos materiais de divulgação das lutas, ações e conquistas dos bairros, como boletins, panfletos, entre outros. Além disso, elaboram, protocolam e armazenam documentos com pedidos para a região e seus moradores, ações possíveis apenas devido ao conhecimento prévio que as lideranças possuem sobre os complexos mecanismos burocráticos das instituições públicas.

Não é possível afirmar que há, da parte das Associações e dos moradores, um planejamento desses lugares como um todo, mas há compartilhamento da compreensão do que são essas periferias urbanas, dos seus problemas e principais conflitos. Algumas lideranças estabelecem, ainda, vínculos e relações com líderes de toda a periferia de Campinas e de outras cidades da Região Metropolitana de Campinas. Participam, inclusive, de encontros e conferências, estaduais e nacionais, com as lideranças de movimentos sociais urbanos. E o fazem por compreenderem que a luta diária para sobreviver ocorre na maior parte do país, de modo que a união e o contato entre as diversas lideranças é uma possibilidade de fortalecê-los.

Problematizamos então que, diante da violência da globalização neoliberal, um saber local, urbano, produtor de um discurso sobre o cotidiano (re)organiza-se. Seria um saber do lugar em oposição ao saber dos experts (SANTOS, 1999). Ao contrário de um "discurso competente" da gestão - preconizado pelas elites como planejamento técnico - esboçam-se ações que tendem a construir uma práxis planejadora levando em conta a conflitualidade (TEIXEIRA e SILVA, 2011).

\section{A PRODUÇÃO DE UMA INFORMAÇÃO ASCENDENTE}

Nas possíveis novas leituras da cidade, a compreensão da natureza política e mercantil do informacional é crucial para elucidar caminhos à ação, bem como construir as múltiplas práxis planejadoras. Daí nossa preocupação em entender a produção e distribuição de informações ascendentes nessas ocupações. Notamos que, em ambas, o acesso às 


\section{CIDADES E CONTRA-RACIONALIDADES: OCUPAÇÕES URBANAS EM CAMPINAS/SP (DO PARQUE OZIEL}

AO JARDIM CAMPO BELO)

informações descendentes ${ }^{13}$ é feito majoritariamente pela televisão. A internet, nas áreas estudadas, só é acessível pelo rádio, que é um meio de baixa velocidade e pouca qualidade. A presença de pequenas lan houses (fixos que permitem o acesso aos computadores e à internet) é pulsante: abrem e fecham constantemente.

$\mathrm{Na}$ região do Jardim Campo Belo encontramos apenas um jornal local, chamado "VIP-Viracopos 14", de caráter estritamente comercial. Já no Parque Oziel há uma rádio local, "Eloi", e um jornal local, "Em Destaque". Ambos são organizados pelo mesmo morador da região e atingem boa parte da periferia urbana espalhada e fragmentada de Campinas. São noticiados acontecimentos do lugar e das diversas e distantes periferias de Campinas, assim como acontecimentos nacionais e mundiais. Trata-se, em certa medida, de uma reprodução da mídia corporativa. A tiragem do jornal é de 24 mil exemplares, os quais são distribuídos em comércios das periferias da cidade. Na região do Jardim Campo Belo, onde o jornal "Em Destaque" também é distribuído, os comerciantes afirmaram que o periódico é bastante procurado e sempre acabam os exemplares. Já com relação à rádio, é possível saber de seu alcance pela participação da população através do telefone e, segundo $o$ dono dos dois veículos de comunicação, participam pessoas de todas as periferias da Macrorregião Sul de Campinas (RIZZATTI, 2015b). Apresentamos abaixo duas notícias do jornal "Em Destaque" sobre as áreas estudadas e uma sobre outra periferia da cidade.
É interessante observar que o jornal local, produzido na ocupação do Parque Oziel, circula nos espaços opacos noticiando o cotidiano, as demandas e reivindicações, o pequeno comércio, entre outros fatos do lugar e de outras periferias de Campinas. Assim, a partir do Parque Oziel, o jornal é difundido para lugares distantes, como o Jardim das Bandeiras (Figura 4) e o Jardim Campo Belo (Figura 3), fomentando a troca de informação local.

\footnotetext{
${ }^{13}$ As informações descendentes são aquelas produzidas e distribuídas pelas mídias hegemônicas, as grandes corporações, e pelo Estado e por isso atendem às necessidades do processo de globalização e do capital (SANTOS, 2000).

${ }^{14}$ É possível levantar a mesma reflexão feita sobre o nome do projeto social VIP-Viracopos.
} 


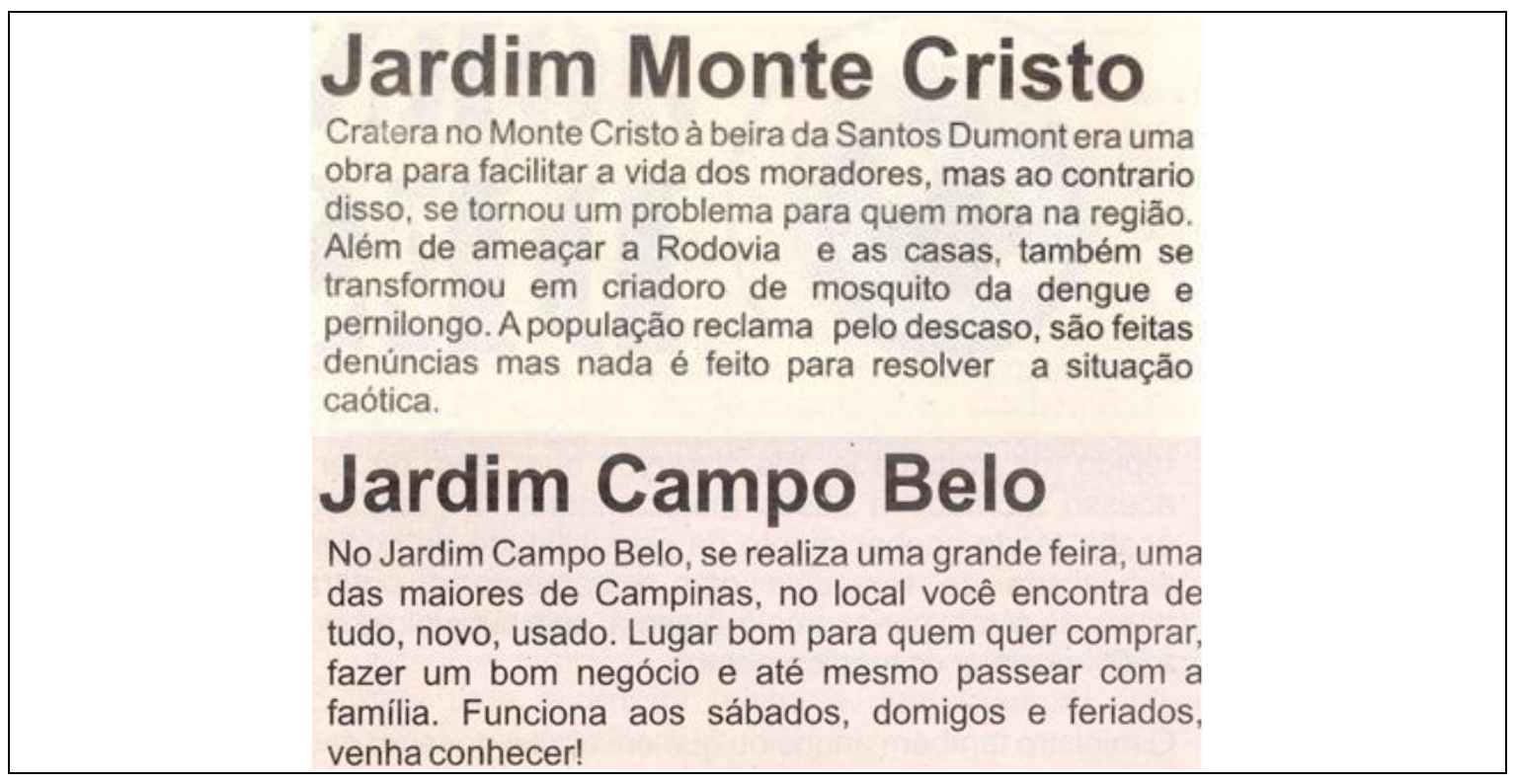

Figura 04 - Notícias dos bairros Jardim Campo Belo e Jardim ${ }^{16}$ - Campinas/SP. Fonte: Jornal "Em Destaque" (2011).

\begin{tabular}{|l|}
\hline Março 2011 \\
Jardim Bandeira II um tradicional bairro de Campinas. \\
Tem problema na Rua Altino Arantes, as calçadas são \\
invadidas por carros, sujeiras e materiais de construções. \\
Deixando muitas vezes um cheiro ruim e acima de tudo \\
dificil para os pedestres. Onde está a fiscalização?
\end{tabular}

Figura 05 - Notícia do bairro Jardim Bandeira II (localizado na Grande Região Sul) - Campinas/SP. Fonte: Jornal “Em Destaque" (2011).

Consideramos essa iniciativa de grande valor para a luta da população urbana espoliada, dentre outros, do direito à informação. Revela um aspecto da luta contra a invisibilidade dessa população silenciada e estereotipada pela mídia hegemônica. A aquisição de tecnologias da informação, seu uso renovado - posto que feito por pessoas de baixa renda (sem um preparo específico, em contraposição à mão-de-obra especializada e cara das grandes corporações) -, indica a possível existência de um consciente coletivo que aprimora e fortalece sua capacidade de organização e planejamento, possíveis através de novos usos dados à materialidade e através das contra-racionalidades dentro do sistema econômico capitalista.

Tanto as Associações de Moradores do Bairro quanto o jornal e a rádio existentes na região do Parque Oziel são produtores e difusores de informações ascendentes (SANTOS, 2000), entendidos como uma informação produzida e distribuída pelos agentes hegemonizados, em contraposição à informação descendente que possui mais o intuito de controlar a população do que informá-la (SILVA, 2012). Souza (2006, p. 228) afirma que

\footnotetext{
${ }^{15}$ O bairro Jardim Monte Cristo é um dos maiores da região do Parque Oziel e foi constituído através da mesma ocupação urbana.
} 


\section{CIDADES E CONTRA-RACIONALIDADES: OCUPAÇÕES URBANAS EM CAMPINAS/SP (DO PARQUE OZIEL AO JARDIM CAMPO BELO)}

é importante ressaltar a necessidade de saber lidar com a informação, dando-lhe um sentido, uma finalidade [...]. Daí a importância de valorizar aquele que aprende a usar a informação, pois esta ajuda na organização dos saberes, permite identificar falhas.

Como também realça Santos (2000), o acesso às tecnologias do período (como é o caso dos computadores, dos transmissores de onda de rádio, das antenas etc.) é um fator indispensável a ser considerado, pois permite novos usos dados a essas técnicas. $\mathrm{O}$ autor ressalta que

- computador, símbolo das técnicas da informação, reclama capitais fixos relativamente pequenos, enquanto seu uso é mais exigente de inteligência [...] e torna-se possível sua adaptação aos mais diversos meios (Idem, p. 164).

Parte das lideranças de Associações de Moradores e dos produtores de informações das ocupações do Jardim Campo Belo e do Parque Oziel demonstram ter conhecimento da sua situação e da necessidade de se organizarem para sobreviver e resistir, pois estes lugares só existem graças à capacidade de construção da parcela da cidade onde os pobres urbanos são obrigados a viver devido à dinâmica especulativa e perversa da urbanização corporativa.

\section{CONSIDERAÇÕES FINAIS}

Trata-se de um período que é uma crise produtora de alienações e esquizofrenias determinadas pelo uso corporativo ostensivo do território (SANTOS, 1997). As grandes cidades condensam o contexto desta crise, fragmentadas entre pontos luminosos das redes globais $\mathrm{e}$ imensos espaços opacos de difícil apreensão onde se trava a luta cotidiana pela reprodução, sobrevivência e resistência.

Neste artigo analisamos as ocupações de terras urbanas para compreender a recente urbanização de Campinas-SP, datada de 1990 até os dias atuais, período no qual as ocupações ganham expressão como importante formaconteúdo da periferia da cidade. O texto apresentou como, nas duas últimas décadas, o crescimento da população pobre, apesar de inferior às taxas de crescimento anuais das décadas de 1970 e 1980, ainda foi maior do que o crescimento da população de média e alta renda. Essa população de baixa renda instala-se, em grande parte, nas inúmeras ocupações urbanas que se constituem majoritariamente na parcela Sul do município e nelas constroem parte da cidade para morar e viver.

Buscamos apresentar como a periferia de Campinas é extensa, difusa, fragmentada e empobrecida, diferindo, portanto, do discurso corriqueiro transmitido pela mídia hegemônica de que Campinas é apenas uma das cidades mais ricas do país. Ora, ela é também uma das cidades com os maiores contingentes populacionais residentes em favelas, loteamentos clandestinos e ocupações urbanas.

Ao adentrarmos as ocupações estudadas reconhecemos a força do lugar, das contraracionalidades, a capacidade de construção de parcela da cidade, de produção e distribuição de informações ascendentes, ou seja, da existência vigorosa de uma nação ativa (SANTOS, 2000) sistematicamente silenciada ou distorcida pela mídia hegemônica (RIZZATTI, 2015b). E há muito que ser feito ainda em termos analíticos para uma melhor compressão dessas insurgências, e lutas (tantas vezes invisíveis) travadas no cotidiano.

\section{REFERÊNCIAS}

CANO, W. Novas determinações sobre a questão regional e urbana após 1980. Texto para discussão. N. 193, IE/UNICAMP, 2011. ISSN 01039466.

CANO, W. \& BRANDÃO, C. A Região Metropolitana de Campinas: urbanização, economia, finanças e meio ambiente. Vols. 1 e 2. Campinas: Unicamp, 2002.

CORRÊA, R. L. O Espaço Urbano. São Paulo: Ática, 2000.

GARCIA, A. Espaços urbanos derivados da implantação de conjuntos habitacionais e áreas 


\section{CIDADES E CONTRA-RACIONALIDADES: OCUPAÇÕES URBANAS EM CAMPINAS/SP (DO PARQUE OZIEL AO JARDIM CAMPO BELO)}

de ocupação ilegal: o caso da região do Distrito Industrial de Campinas. 2010. Dissertação. (Mestrado em Arquitetura e Urbanismo). FEC, Unicamp, Campinas-SP, 2010.

GHILARDI, F. O lugar dos pobres na cidade de Campinas-SP: questões a partir da urbanização da ocupação do Parque Oziel, Jardim Monte Cristo e Gleba B. 2012. Dissertação. (Mestrado em Arquitetura). IAU, EESC, USP, São Carlos-SP, 2012.

HARVEY, D. O novo imperialismo. São Paulo, Edições Loyola, 2004.

HELENE, Diane; ANDREOTTI, Maria Beatriz \& MARINO, Filipe. A segregação espacial planejada: uma análise da urbanização da cidade de Campinas-SP. 2011. Disponível em: $<$ www.academia.edu/4186428/>. Acessado em: Setembro de 2013.

JACOBI, P. Exclusão urbana e lutas pelo direito à moradia. Espaço \& Debates, no 7, p. 53-69, out./dez. 1982.

LENCIONE, S. Reestruturação urbano-industrial no estado de São Paulo: a região da metrópole desconcentrada. Espaço \& Debate, n. 38, p. 5461, 1994.

LOJKINE, J. A revolução informacional. São Paulo: Cortez, 1995.

LOPES, D. O movimento da Assembléia do Povo e a Crítica da 'Marginalidade'. 1988. Dissertação. (Mestrado em Sociologia), IFCH, Unicamp, Campinas-SP, 1988.

MESTRE, A. Os usos do território e as políticas urbanas: o Jardim Campo Belo no processo de fragmentação da cidade de Campinas. 2009. Dissertação. (Mestrado em Geografia), IG, Unicamp, Campinas-SP, 2009.

MESTRE, A. \& FONSECA, H. O Plano Diretor e a regionalização como ferramenta do planejamento de Campinas: uma análise da região do Jardim Campo Belo. Boletim Geográfico de Campinas, Campinas, v. 1, n. 1, p. 31-46, 2011.

RIBEIRO, A. C. T. Sociabilidade hoje: leituras da experiência urbana. Cadernos $\mathrm{CRH}$. Salvador, v.18, n. 45, p. 411-422, set/dez, 2005.

Cidade e capitalismo periférico: em direção à experiência popular. Margem Esquerda v.12, p. 25-31, 2008.
Por uma sociologia do presente: ação técnica e espaço. Rio de Janeiro: Letra Capital, 2013.

RIZZATTI, H. O recente processo de urbanização da cidade de Campinas-SP (1990-2014): as ocupações urbanas - um estudo dos usos do território na Região Sul. 2014 Dissertação. (Mestrado em Geografia), IG, Unicamp, Campinas-SP, 2014.

As maiores ocupações urbanas da cidade de Campinas-SP: resistências e permanência. Revista de Ciências HUMANAS, Florianópolis, v. 49, n. 2, p. 183-204, jul-dez, $2015 a$.

A urbanização de Campinas/SP e a produção de informação nas maiores ocupações da cidade. RUA [online], vol. 2, n. 21, p. 221-245, junho, 2015b.

RODRIGUES, A. M. Moradia nas cidades brasileiras. São Paulo: Editora Contexto, 1988.

Propriedade fundiária urbana e controle socioespacial. Scripta Nova (Barcelona). v. XVIII, p. 1-17, maio, 2014.

ROLNIK, R. Guerra dos lugares: a colonização da terra e da moradia na era das finanças. São Paulo: Boitempo, 2015.

SANTOS, A. Campinas, das Origens ao Futuro: Compra e Venda de Terra e Água e um Tombamento na Primeira Sesmaria da Freguesia de Nossa Senhora da Conceição das Campinas do Mato Grosso de Jundiaí (1732-1992). CampinasSP: Unicamp, 2002.

SANTOS, M. Metrópole corporativa e fragmentada: o caso de São Paulo. São Paulo: Nobel, 1990.

A natureza do espaço: técnica e tempo, razão e emoção. São Paulo: Hucitec, 1996.

- Da política dos Estados à política das empresas. Cadernos da Escola do Legislativo,3(6):3-19, jul/dez.1997.

O território e o saber local: algumas características de análise. Cadernos IPPUR, Ano XIII, n.o 2, p.15-26, 1999.

Por uma outra globalização: do pensando único à consciência universal. São Paulo: Record, 2000. 


\section{CIDADES E CONTRA-RACIONALIDADES: OCUPAÇÕES URBANAS EM CAMPINAS/SP (DO PARQUE OZIEL AO JARDIM CAMPO BELO)}

A urbanização brasileira. 5a Ed. São

Paulo: Hucitec, 2008 [1993].

SANTOS, M \& SILVEIRA, M. L. O Brasil: território e sociedade no início do século XXI. São Paulo: Record, 2001.

SANTOS, R. B. Campinas como pólo tecnológico na reestruturação do espaço urbano regional. In: CARLOS, A. F.; LEMOS, A. I. G. (orgs.) Dilemas Urbanos: Novas Abordagens sobre as Cidades. São Paulo: Editora Contexto, 2000. p. 204-211.

SILVA, A. M. B. As grandes cidades e o período popular da história: contribuições ao debate. In: SILVA, M. A. et al (Orgs) Encontro com o pensamento de Milton Santos. Salvador, Empresa Gráfica da Bahia, 2006.

_. Círculos de informações, urbanização e usos do território brasileiro. Revista da ANPEGE, v. 8, n. 10, p. 3-15, ago./dez. 2012

SILVEIRA, M. L. Globalización y território usado: imperativos y solidariedades. Cuadernos del CENDES, ano 25, n 69, p. 01-19, set-dez, 2008.

SOUZA, M. A. de (org). A Metrópole e o Futuro: Refletindo sobre Campinas. Campinas-SP: Territorial, 2008.

SOUZA, M. L. de. A prisão e a ágora: reflexões em torno da democratização do planejamento e da gestão das cidades. Rio de Janeiro: Bertrand Brasil, 2006.

A cidade, a palavra e o poder: práticas, imaginários e discursos heterônomos e autônomos na produção do espaço urbano. In.: CARLOS, A. F.; SOUZA, M. L. \& SPOSITO; M. E. B. (orgs.). A Produção do Espaço Urbano: agentes e processos, escalas e desafios. São Paulo: Contexto, 2011. p. 147-166.

TEIXEIRA, S. H. e SILVA, A. M. B.. Os usos da informação estratégica sobre o território: A empresa de consultoria PriceWaterHouseCoopers e o Planejamento territorial. Revista Brasileira de Estudos Urbanos e Regionais, v. 13, n. 2, p. 71-85, 2011.

\section{DOCUMENTOS CONSULTADOS}

$\begin{array}{lrrr}\text { INSTITUTO } & \text { BRASILEIRO DE } & \text { GEOGRAFIA E } \\ \text { ESTATÍSTICA. } & \text { Aglomerados } & \text { Subnormais. }\end{array}$ Primeiros Resultados. Ministério do Planejamento, Orçamento e Gestão. Censo Demográfico. 2010. Rio de Janeiro, 2011. (p. 1259)
PREFEITURA MUNICIPAL DE CAMPINAS. Plano Diretor. Secretaria de Planejamento, Desenvolvimento Urbano e Meio Ambiente (SEPLAMA). Campinas-SP, 2006.

Plano Municipal de Habitação. Secretaria Municipal de Habitação. Campinas-SP, 2011, (p. 1- 487)

MANIFESTO contra a 'política habitacional' adotada no município de Campinas, 26 de setembro de 2013. Disponível em: <http://agbcampinas.com.br/site/2013/09>. Acessado em: 11 de agosto de 2015. (3p.) 